\title{
Impacts of intervention objectives in goat production within subsistence farming systems in South Africa
}

\author{
M.J.E. Braker ${ }^{1}$, H.M.J. Udo ${ }^{1 \#}$ and E.C. Webb $^{2}$ \\ ${ }^{1}$ Animal Production Systems Group, Wageningen Institute of Animal Sciences, Wageningen University, \\ P.O. Box 338, 6700 AH Wageningen, The Netherlands \\ ${ }^{2}$ Department of Animal and Wildlife Science, University of Pretoria, Pretoria 0002, South Africa
}

\begin{abstract}
The aims of this research were to study goat production in the rural areas of South Africa and to explore the impact of intervention objectives, namely an increase in kidding percentage and a decrease in kid losses (mortalities, theft and predation) on goat production in subsistence farming systems. A personal interview survey was conducted in three communities in South Africa, namely Jericho (Northwest Province), Bolahlakgomo (Northern Province) and Schoonoord (Northern Province). In each community, traditional purposes and meat consumption were important reasons for keeping goats. Other reasons mentioned were used to characterise the systems and were commercially-orientated in Jericho, social reasons in Bolahlakgomo and of a supportive nature in Schoonoord. The average herd size was 16.2 animals in Jericho, 7.7 animals in Bolahlakgomo and 40.1 animals in Schoonoord. The most important expenses incurred were for veterinary products, while that for feed and veterinary services were relatively low. Most important outputs included the slaughter for home consumption, sale of live animals and ceremonial uses. Mortalities were similar in the three communities; theft was high in Jericho and predation was high in Bolahlakgomo. Economic values based on gross margin calculations were R864 in Jericho, R382 in Bolahlakgomo and $\mathrm{R} 1,569$ in Schoonoord. Intervention objectives yielded economic values of R1,887 in Jericho and R934 in Bolahlakgomo. No intervention objectives were proposed for Schoonoord. From this research it is concluded that intervention objectives have different outcomes in different communities. The success of commercialisation of livestock production in general is based on the location of the community, accessibility of knowledge and markets, and production goals of the household.
\end{abstract}

Keywords: Farming systems, subsistence, goats

${ }^{\#}$ Corresponding author. E-mail: Henk.Udo@dps.vh.wag-ur.nl

\section{Introduction}

Goats are kept traditionally by a large part of the population in the rural areas of South Africa (Els, 1996). These goats fulfil important roles within the households of subsistence farming systems in these rural areas. They are used to maintain social bonds with the community, e.g. as lobola (dowry) (Tapson, 1993) and as exchange with relatives. Goats are also used for ceremonial (Dombo et al., 1999) or religious purposes (Els, 1996), and they provide an income as well as meat and milk for the household (Tapson, 1993).

At present, the improvement of goat production receives attention from the National Department of Agriculture, provincial departments of agriculture, universities and Non-Governmental Organisations (NGOs). Goat production is regarded as a feasible means to improve the income and nutrition of rural communities and to incorporate these communities into commercial markets.

It is important to characterise diverse production systems and benefit streams. The aims of this research were to study goat production in the rural areas of South Africa and to evaluate the possible impact of intervention objectives in goat production within subsistence farming systems.

\section{Material and Methods}

A personal interview survey was conducted to gain insight into the farming systems of rural households in three communities in South Africa, namely Jericho (Mabopane district, Northwest Province), Bolahlakgomo (Groothoek district, Northern Province) and Schoonoord (Sekhukhune district, Northern Province). These communities were selected based on existing partnerships among the Department of Paravetererinary Studies at the University of Pretoria and the community of Jericho, among the Animal Improvement Institute of the Agricultural Research Council and the farmers' organisation BOLIFO in Bolahlakgomo, and among the Post Graduate School for Agriculture and Rural Development and the Provincial Department of Agriculture in Schoonoord. 
Thirteen households were interviewed in Jericho during October and November 2000; all households kept goats. Sixty households were interviewed in Bolahlakgomo during October 2000; 28 households kept goats. Twenty-eight households were interviewed in Schoonoord during January and February 2001; 16 households kept goats. A questionnaire was designed to obtain information about the respondent, household, land, water, fuel, labour, crop production and animal production. The questionnaire on animal production focussed on social, economic and technical topics e.g. number and breed of animals kept; reasons for keeping livestock; ownership and decision-making; traditional uses; grazing arrangements and additional feedstuffs used; purchase of inputs; animal products used for home consumption and sale; mortalities, theft and predation; animal purchase and use of manure. Numbers of animals were converted into Large Stock Units (LSU), where a doe is $0.17 \mathrm{LSU}$, a buck $0.22 \mathrm{LSU}$, a castrate $0.17 \mathrm{LSU}$ and a kid $0.12 \mathrm{LSU}$ (Meissner et al., 1983).

Economic values of the sub-systems were calculated based on gross margin calculations, which included product utilisation. Costs of the sub-system included the purchase of feed, veterinary products, veterinary services and live animals. Benefits of the sub-system were cash income and product utilisation, such as lobola, ceremonial uses, exchange with relatives and home consumption of milk and meat. Values of animals used for product utilisation were estimated based on prevailing prices of live animals in each of the three research areas. Total household income was defined as the sum of the economic values for all subsystems present within the household and off-farm income.

A cost benefit model was constructed based on all inputs and outputs of the sub-system. This model was used to predict the possible effects of intervention objectives on the sub-system by means of extrapolation. The opportunity cost for family labour was added to the model to analyse the effects of the intervention objectives on the household labour situation. The opportunity cost for family labour was calculated in South African Rand based on a minimum wage of R1.25 (R1 was equivalent to US\$0.12 in August 2001) per hour of unskilled adult labour. The intervention objectives in the system were an increase in kidding percentage and a decrease in percentage of kid loss (kid loss includes mortalities, theft and predation). Intervention objectives were analysed in three steps: both intervention objectives separately and the two intervention objectives together. Only the last intervention objective will be considered here. These intervention objectives were proposed based on fast and visible results, ease of adoption and low financial inputs required. The intervention objectives were based on what could realistically be expected in each of the communities. In Jericho, kidding percentage could only be increased from $81 \%$ to $100 \%$, because of water quality problems in the region (Casey \& Meyer, 2001). Here, percentage of kid loss was estimated to decrease from $34 \%$ to $7 \%$. In Bolahlakgomo, kidding percentage was estimated to increase form $62 \%$ to $100 \%$. Here, percentage of kid loss could only be decreased from $44 \%$ to $10 \%$, because of high predation risks in the region. For Schoonoord, no intervention objectives were proposed, because of a lack of interest of the population.

The means of various values of the three goat sub-systems were compared in SPSS using GLM procedures (SPSS, 1989). Differences among these means were compared using the Boneferroni range test to compensate for the differences in the number of observations per community.

\section{Results and Discussion}

Reasons for keeping goats in the three communities are summarised in Table 1. The households gave more than one answer and, therefore, the number of answers was larger than the number of households interviewed. Reasons for keeping goats differed slightly among communities. In Jericho, the main reasons given were for household meat production (30\%), security (easily convertible into money in times of need) (27\%), traditional purposes (15\%) and commercial reasons (15\%). Households in Bolahlakgomo kept goats mainly for meat production (38\%), traditional purposes (38\%) and companionship (10\%), while in Schoonoord goats were kept for traditional purposes $(29 \%)$, manure $(25 \%)$ and security $(15 \%)$. It all three communities it was evident that goats are kept mainly for household meat consumption and traditional purposes. The other reasons for keeping goats were used to characterise the production systems in each community. In Jericho, goat production was characterised as a commercially-orientated production system, because the sale of live animals was an important reason for keeping goats. In Bolahlakgomo, goat production was characterised as a social system, because companionship of goats was important. In Schoonoord, goat production was characterised as a supportive system, because production of manure for crop production was important. 
Table 1 Summary of reasons for keeping goats in three communities in South Africa (expressed as a percentage)

\begin{tabular}{llc}
\hline Community & Reason for keeping goats & Percentage $(\%)$ \\
\hline Jericho $(\mathrm{n}=33)$ & Meat & 30 \\
& Security ${ }^{*}$ & 27 \\
& Commercial/Sale & 15 \\
& Tradition $^{* *}$ & 15 \\
& Companionship & 9 \\
Milk & 3 \\
& Meat & 38 \\
Bolahlakgomo $(\mathrm{n}=39)$ & Tradition & 38 \\
& Companionship & 10 \\
& Security & 8 \\
& Commercial/Sale & 5 \\
& & 5 \\
& Tradition & 29 \\
& Manure & 25 \\
& Security & 15 \\
& Milk & 10 \\
& Meat & 10 \\
\end{tabular}

*Animals used as an easily convertible source of income in times of need

** Animals used for traditional and religious purposes

Table 2 General composition of the goatherd in three communities in South Africa

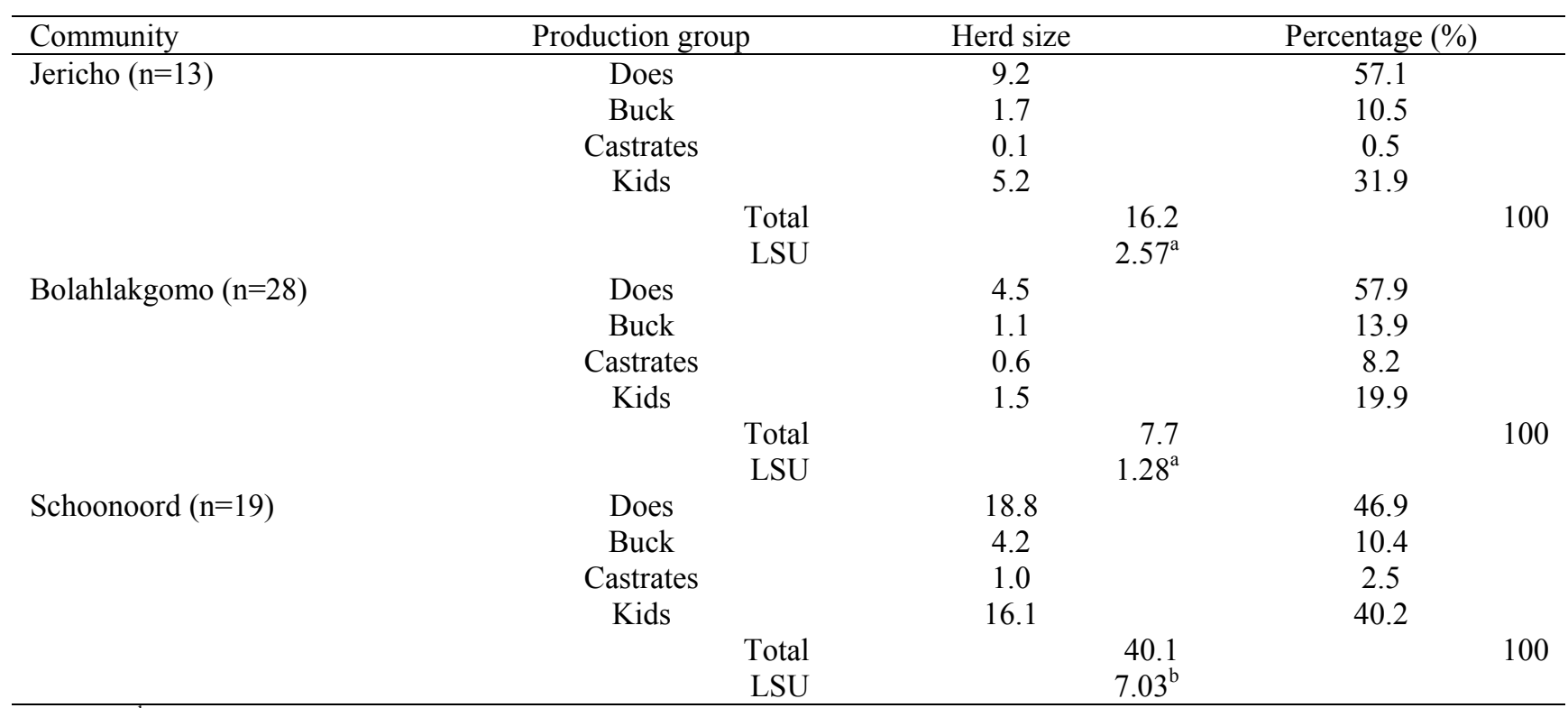

${ }^{\mathrm{ab}}$ Statistical difference $\mathrm{P}<0.05$

Goatherds kept by the households calculated in LSU differed in size $(\mathrm{P}<0.05)$. Herd sizes ranged from 1.28 LSU in Bolahlakgomo to 7.03 LSU in Schoonoord (Table 2). The average herd size was 16.2 goats in Jericho, 7.7 goats in Bolahlakgomo and 40.1 goats in Schoonoord. Kidding percentages were approximately $81 \%$ in Jericho, $62 \%$ in Bolahlakgomo and $63 \%$ in Schoonoord. These differences can be explained by limited mating in small breeding herds, which are often without bucks, and by inbreeding within the herd.

In Jericho, households spent on average only one hour a day on management of goats, in Bolahlakgomo about 4 hours a day, and in Schoonoord 5.5 hours a day. The elderly head of the household or a young boy (son or grandson) usually looked after the goats. Labour was hired in two households. In most 
households, the male or female head made decisions regarding goats. Inputs invested into goatherds in the different communities are presented in Table 3.

Table 3 Inputs (in SA Rand) for goatherds per household in the three communities expressed per herd and per LSU

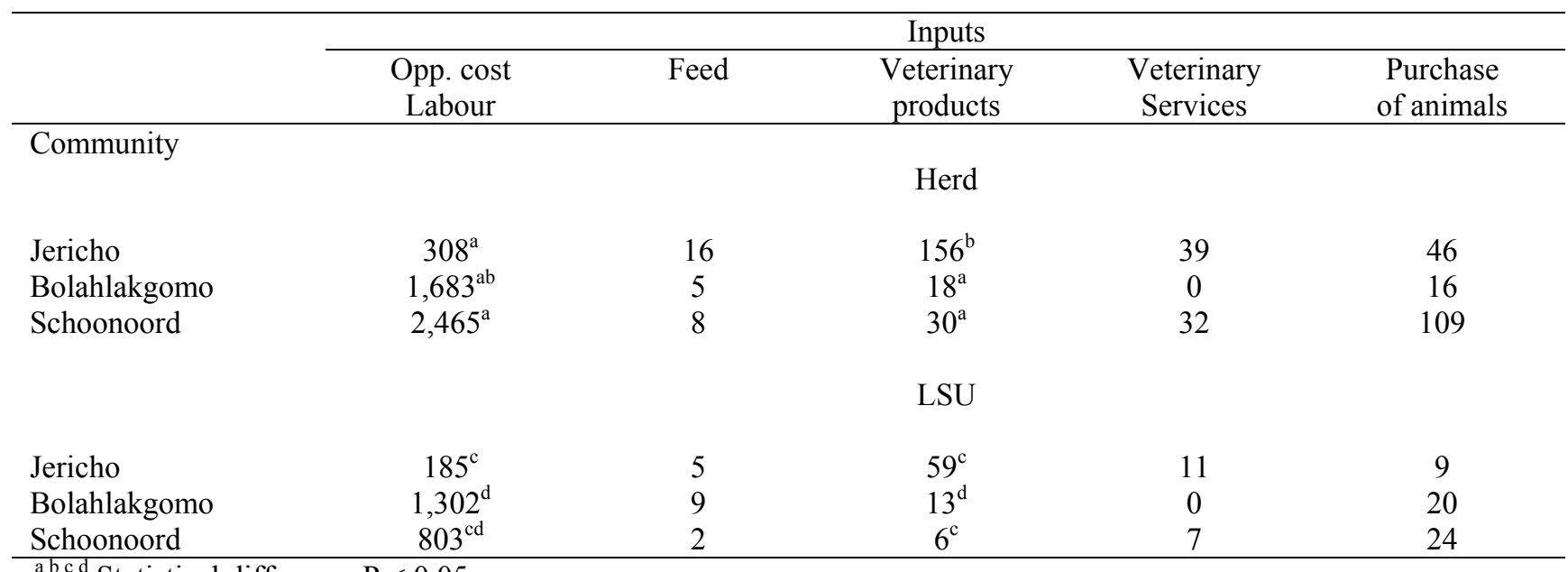

${ }^{a b c d}$ Statistical difference $\mathrm{P}<0.05$

For the complete herd the opportunity cost of family labour invested in Jericho (R308) differed significantly $(\mathrm{P}<0.05)$ from that in Schoonoord $(\mathrm{R} 2,465)$. Calculated per LSU, family labour differed significantly $(\mathrm{P}<0.05)$ between Jericho $(\mathrm{R} 185)$ and Bolahlakgomo $(\mathrm{R} 1,302)$. The amount of money spent on veterinary products in Jericho $(\mathrm{R} 156)$ also differed significantly $(\mathrm{P}<0.05)$ compared to that spent in both Bolahlakgomo (R18) and Schoonoord (R30). The total amount of money spent on feed and veterinary services was generally quite low $(<\mathrm{R} 40$ per herd). The high expenditure on veterinary products in Jericho (R156) can probably be attributed to the proximity to Pretoria and Brits and the high involvement of the University of Pretoria, the Medical University of Southern Africa (Medunsa) and the Provincial Department of Agriculture in this area.

The monetary value of goat products used for home consumption or sale is presented in Table 4.

Table 4 Monetary value (in SA Rand) for goatherds per household in the three communities expressed per herd and per LSU

\begin{tabular}{|c|c|c|c|c|c|c|c|c|c|c|}
\hline & \multicolumn{10}{|c|}{ Products } \\
\hline & \multicolumn{2}{|c|}{ Milk } & \multicolumn{2}{|c|}{ Meat } & \multicolumn{2}{|c|}{ Lobola } & \multicolumn{2}{|c|}{ Relatives } & \multirow{2}{*}{$\begin{array}{c}\text { Live } \\
\text { animals } \\
\text { Sale }\end{array}$} & \multirow{2}{*}{$\begin{array}{c}\text { Ceremonial } \\
\text { purposes } \\
\text { Use }\end{array}$} \\
\hline & Home & Sale & Home & Sale & Given & Received & Given & Received & & \\
\hline \multicolumn{11}{|l|}{ Community } \\
\hline & & & & & & Herd & & & & \\
\hline Jericho & 13 & 0 & 398 & 0 & 0 & 0 & 17 & 23 & 577 & 92 \\
\hline Bolahlakgomo & 18 & 0 & 614 & 0 & 0 & 0 & 14 & 0 & 41 & 32 \\
\hline \multirow[t]{2}{*}{ Schoonoord } & 679 & 20 & 407 & 40 & 50 & 50 & 0 & 40 & 276 & 213 \\
\hline & & & & & & LSU & & & & \\
\hline Jericho & 9 & - & $294^{\mathrm{ab}}$ & - & - & - & 6 & 8 & 255 & 39 \\
\hline Bolahlakgomo & 26 & - & $474^{\mathrm{a}}$ & - & - & - & 7 & 0 & 25 & 23 \\
\hline Schoonoord & 58 & 3 & $69^{\mathrm{b}}$ & 7 & 11 & 11 & 0 & 9 & 26 & 29 \\
\hline
\end{tabular}

${ }^{\mathrm{a} b}$ Statistical difference $\mathrm{P}<0.05$

The monetary value of goats used for home consumption expressed per LSU in Bolahlakgomo (R474) differed significantly $(\mathrm{P}<0.05)$ from that of Schoonoord $(\mathrm{R} 69)$. Monetary values of goats used for home consumption expressed per herd were similar (R450) among the communities. This means that herd size did 
not influence the number of animals slaughtered for home consumption. Only households in Schoonoord sold milk and meat, the other communities did not sell produce. The sale of live animals tended to be higher $(\mathrm{P}<0.1)$ in Jericho (R577) as opposed to the other communities. The higher sales of animals suggest a more commercialised form of goat farming in Jericho, compared with the other communities.

Use of goats for lobola and exchange with relatives were of minor importance in these communities and accounted for less than R50 per herd per year. The most important traditional use of goats was for ceremonial purposes that amounted to R92 in Jericho, R32 in Bolahlakgomo and R213 in Schoonoord. The value per LSU was about the same (R31) for the three communities, which means that the number of animals owned influenced the number of animals used for ceremonial purposes.

High losses occurred, due to mortalities, theft and predation. Monetary values of these losses are presented in Table 5.

Table 5 Monetary value (in SA Rand) of goat losses per household in the three communities

\begin{tabular}{lccc}
\hline & & Goat losses & \\
\hline & Mortalities & Theft & \\
\cline { 2 - 4 } Community & & Herd & \\
& & $329^{\mathrm{b}}$ & 127 \\
Jericho & 721 & $27^{\mathrm{ab}}$ & 181 \\
Bolahlakgomo & 348 & $20^{\mathrm{a}}$ & \\
Schoonoord & 1,462 & LSU & \\
& & & 48 \\
& & 382 & 113 \\
Jericho & 302 & 15 & 32 \\
Bolahlakgomo & 276 & 4 & \\
Schoonoord & 341 & &
\end{tabular}

${ }^{\mathrm{ab}}$ Statistical difference $\mathrm{P}<0.05$

Mortalities expressed in terms of LSU, were similar (R300) in the three communities. The incidence of theft expressed per LSU was high in Jericho (R329), while predation expressed per LSU was high in Bolahlakgomo (R113). Theft was expected to be high in Jericho due to the proximity of the community to densely populated areas, the low amount of time invested in goat management and reasonable infrastructure in the area. The occurrence of predation in Bolahlakgomo was expected to be high due to the rural surroundings of the village. Table 6 .

The economic values of goat production per household in the three communities are summarised in

Table 6 Economic values (in SA Rand) of goat production per household for the three communities

\begin{tabular}{lc}
\hline & Economic value \\
\hline Community & Herd \\
& \\
Jericho & 864 \\
Bolahlakgomo & 382 \\
Schoonoord & 1,569 \\
& LSU \\
& \\
Jericho & 336 \\
Bolahlakgomo & 296 \\
Schoonoord & 253 \\
\hline
\end{tabular}

Income generated, expressed per LSU, was the highest in Jericho (R336), which is attributed to the more commercially-orientated farming systems and to the proximity to markets in Pretoria and Brits. 
Household income and income from other activities are presented in Table 7.

Table 7 Summary of household income (in SA Rand) per household for different communities

\begin{tabular}{|c|c|c|c|c|c|c|c|c|c|c|c|c|}
\hline & $\begin{array}{l}\text { Off- } \\
\text { Farm } \\
\text { Income }\end{array}$ & $\begin{array}{l}\text { Hired } \\
\text { labour }\end{array}$ & $\begin{array}{l}\text { Hired } \\
\text { out } \\
\text { labour }\end{array}$ & $\begin{array}{l}\text { Other } \\
\text { activi- } \\
\text { ties }\end{array}$ & Crops & Cattle & Chickens & Donkeys & Sheep & Pigs & Goats & Total \\
\hline \multicolumn{13}{|c|}{ Community } \\
\hline Jericho & $\begin{array}{l}10,726 \\
\pm 4,440\end{array}$ & $\begin{array}{l}-45 \\
\pm 89\end{array}$ & 0 & $\begin{array}{l}200 \\
\pm 693\end{array}$ & $\begin{array}{l}209 \\
\pm 309\end{array}$ & $\begin{array}{l}578 \\
\pm 8,840\end{array}$ & $\begin{array}{l}-49 \\
\pm 431\end{array}$ & $\begin{array}{l}698 \\
\pm 1,094\end{array}$ & $\begin{array}{l}4 \\
\pm 72\end{array}$ & $\begin{array}{l}-410 \\
\pm 1,477\end{array}$ & $\begin{array}{l}864 \\
\pm 1,031\end{array}$ & $\begin{array}{l}13,770 \\
\pm 9,630\end{array}$ \\
\hline $\begin{array}{l}\text { Bolahla- } \\
\text { Kgomo }\end{array}$ & $\begin{array}{l}21,278 \\
\pm 26,999\end{array}$ & $\begin{array}{l}-682 \\
\pm 1,710\end{array}$ & $\begin{array}{l}5 \\
\pm 39\end{array}$ & $\begin{array}{l}250 \\
\pm 1,176\end{array}$ & $\begin{array}{l}474 \\
\pm 701\end{array}$ & $\begin{array}{l}1,797 \\
\pm 3,555\end{array}$ & $\begin{array}{l}305 \\
\pm 1,312\end{array}$ & $\begin{array}{l}103 \\
\pm 453\end{array}$ & $\begin{array}{l}24 \\
\pm 165\end{array}$ & ND & $\begin{array}{l}174 \\
\pm 495\end{array}$ & $\begin{array}{l}23,184 \\
\pm 26,832\end{array}$ \\
\hline $\begin{array}{l}\text { Schoon- } \\
\text { Oord }\end{array}$ & $\begin{array}{l}48,073 \\
\pm 31,788\end{array}$ & $\begin{array}{l}-234 \\
\pm 775\end{array}$ & $\begin{array}{l}165 \\
\pm 303\end{array}$ & $\begin{array}{l}105 \\
\pm 459\end{array}$ & $\begin{array}{l}66 \\
\pm 52\end{array}$ & $\begin{array}{l}5,880 \\
\pm 4,264\end{array}$ & $\begin{array}{l}197 \\
\pm 269\end{array}$ & $\begin{array}{l}258 \\
\pm 750\end{array}$ & ND & $\begin{array}{l}17 \\
\pm 71\end{array}$ & $\begin{array}{l}1,280 \\
\pm 2,696\end{array}$ & $\begin{array}{l}57,172 \\
\pm 18,454\end{array}$ \\
\hline
\end{tabular}

The household incomes in Jericho (R13,770), Bolahlakgomo (R23,184) and Schoonoord (R57,172) were mainly from off-farm activities or pensions. The contributions of off-farm activities and pensions were R10,726 in Jericho, R21,278 in Bolahlakgomo and R48,073 in Schoonoord. Farming activities contributed only a small proportion to the household income. In Jericho, the most important on-farm income sources were goats (R864) and cattle (R578). In Bolahlakgomo, these were cattle (R1,797), crops (R474) and goats (R174) and in Schoonoord, these were cattle $(\mathrm{R} 5,880)$ and goats $(\mathrm{R} 1,280)$.

The actual scenarios of goat production were used as starting point for the intervention objectives proposed. These intervention objectives were increased kidding percentage and decreased kid loss. In Jericho, kidding percentage was increased from $82 \%$ to $100 \%$ and kid loss decreased from $34 \%$ to $7 \%$. In Bolahlakgomo, kidding percentage was increased from $62 \%$ to $100 \%$ and kid loss decreased from $44 \%$ to $10 \%$. The increased herd sizes and increased inputs, outputs and economic values are presented in Table 8 .

Table 8 Impacts of intervention objectives in Jericho and Bolahlakgomo on the financial inputs, outputs and economic value of goat sub-system per household in the three communities

\begin{tabular}{lccccccc}
\hline & $\begin{array}{c}\text { Herd size } \\
\text { (animals) }\end{array}$ & $\begin{array}{c}\text { LSU } \\
\text { (LSU) }\end{array}$ & $\begin{array}{c}\text { Inputs } \\
\text { (Rand) }\end{array}$ & $\begin{array}{c}\text { Opp. Cost } \\
\text { Labour } \\
\text { (Rand) }\end{array}$ & $\begin{array}{c}\text { Outputs } \\
\text { (Rand) }\end{array}$ & $\begin{array}{c}\text { Ec. Value } \\
1^{\text {st }} \text { year } \\
\text { (Rand) }\end{array}$ & $\begin{array}{c}\text { Ec. Value } \\
\text { next years } \\
\text { (Rand) }\end{array}$ \\
\hline $\begin{array}{l}\text { Community } \\
\text { Jericho }\end{array}$ & & & & & & & \\
$\quad \begin{array}{c}\text { Present } \\
\text { Future }\end{array}$ & 16.2 & 2.6 & 211 & 308 & 1,074 & 864 & 1,027 \\
$\begin{array}{c}\text { Bolahlakgomo } \\
\text { Present }\end{array}$ & 19.6 & 3.0 & 255 & 373 & 1,283 & & 1,887 \\
$\quad$ Future & 7.7 & 1.3 & 32 & 1,683 & 436 & 382 & \\
\hline
\end{tabular}

The results suggest that the proposed intervention objectives in Jericho could increase the income from R864 to R1,027 in the first year and to R1,887 in the following years. This increase in income combined with the fact that goat production appears to be the most important source of income in this community indicates that the intervention objectives may improve goat production in these systems. When introducing intervention objectives, however, it has to be taken into consideration that the community consists mainly of elderly, poorly educated people, who hesitate to take agricultural risk.

In Bolahlakgomo, income rose from R382 to R499 in the first year and to R934 in the following years. There was an increase in opportunity cost for family labour, however, which rose from R1,683 to R2,222. It was apparent from the survey that extra labour is not available. In Bolahlakgomo, the potential for improvements in cattle production appears to be more promising, based on the high income generated (Table 7). Intervention objectives in cattle production should, therefore, be proposed in Bolahlakgomo. Here again, when introducing intervention objectives it has to be taken into consideration that the community consists mainly of elderly, poorly educated people, who hesitate to take agricultural risk.

In Schoonoord, the community was not interested to invest time and money into animal production. This lack of interest might be related to high off-farm incomes generated by households. Households were 
less dependent on agriculture and, therefore, lacked the need to improve their farming activities; they were less interested to invest in agriculture and they were less willing to take risks in this sector. The exact limitations of intervention objectives in agricultural activities in this area require more research, because improvements in agriculture can be expected, especially in cattle and crop production, based on income generated.

There are important differences between the three communities surveyed. Jericho has an advantage over the other two communities, because of its proximity to large cities. This proximity influences the availability of products and services, and it ensures availability of output markets. The proximity of the knowledge centres, such as the University of Pretoria and Medunsa is assumed to be the cause of the higher use of veterinary products in the households in Jericho, compared to Bolahlakgomo and Schoonoord.

Bolahlakgomo is situated far from larger centres, which isolates the community and makes products and services difficult to obtain. This isolation also influences the prices of animals sold at auctions; the average price obtained was lower in Bolahlakgomo than in Jericho or Schoonoord. In Schoonoord, the prices of animals and availability of inputs were better because it is situated closer to the metropolitan areas. Another advantage of Schoonoord is its higher-educated population, influencing the knowledge available on goat management. It appears that the location of the community, the education level of the farmers and availability of input and output markets and services result in major differences among communal farming systems. These differences affect the economic performance of subsistence farming systems.

\section{Conclusions}

Goat production in subsistence farming systems in rural areas of South Africa only contributes a small proportion of the total household income earned. Differences in production systems among different communities become clear when the main features of goat production, namely the reasons for keeping goats, herd size, kidding percentage, inputs, labour, cash outputs, product utilisation, social obligations and losses are evaluated. The impact of intervention objectives in goat production can vary widely, ranging from small financial inputs, in the form of feed and veterinary products, to large labour inputs, in the form of family labour, resulting in a doubling of the initial income from goats. The results of intervention objectives should be seen, however, against the background of the household and the community. A proper understanding of the initial farming system, is, therefore, needed before intervention objectives are proposed. Prerequisites for commercialisation of livestock in general are commercially-orientated production goals of households, proximity of communities to larger centres, and availability of knowledge and markets for inputs and outputs.

\section{Acknowledgements}

The authors wish to thank C. McCrindle and J. Sebei of the Department of Paraveterinary Studies, S. Nieuwoudt, L. Krüger and L. Morale of ARC-AII and J. Mamabolo of the Post Graduate School for Agriculture and Rural Development for their assistance in collecting the data. This research was financed by the South Africa - Netherlands Research Programme on Alternatives in Development (SANPAD).

\section{References}

Casey, N.H. \& Meyer J.A., 2001. An extension to and further refinement of a Water Quality Guideline Index System for Livestock Watering. Volume 1. Rural Communal Livestock Production Systems and Wildlife Production Systems. Water Research Commission Final Report No. K5-857-0-1.

Dombo, H., Kitney, S., Maluleka, T., \& Smuts, M., 1999. Goat Management Manual for Goat Owners. Agricultural Research Council - Goat Programme, ARC - Animal Nutrition and Products Institute, Irene, South Africa.

Els, H., 1996. Socio-economics of the animal husbandry in the rural communal areas of South Africa. In: Socio-economics of Veterinary Research and Training: A Forum. Eds. McCrindle, C.M.E. \& Krecek, E.C., MEDUNSA, Pretoria.

Meissner, H.H., Hofmeyr, H.S., Van Rensburg, W.J.J.\& Pienaar, J.P., 1983. Classification of livestock for realistic prediction of substitution values in terms of a biologically defined Large Stock Unit. Technical Communication No. 175. Department of Agriculture, Pretoria (RSA).

SPSS, 1989. SPSS for windows, Release 9.0.1.

Tapson, D.R., 1993. The economic institutional role of livestock in developing countries. Proc. Livestock Production under Traditional Systems. Irene Animal Production Institute, South Africa, April 1993. 